\title{
Laparoscopic staple interruption versus laparoscopic varicocelectomy for the treatment of varicocele value and effect: A comparative study
}

\author{
Ghada Morshed, MD, MRCS; Hany Habashy, MD
}

Department of Surgery, El-Fayoum University Hospital, Fayoum, Egypt.

\begin{abstract}
Background: Varicocele is an abnormal dilation of the pampiniform plexus that constitutes the primary drainage of the testis. It is found approximately in 15\% of male adolescents with a left sided predominance. Laparoscopic varicocelectomy has been proposed as an alternative surgical procedure for the repair of varicocele with reported benefits of better convalescence, minimal invasiveness and less analgesic requirement postoperatively.

Patients and methods: The study was done in El Fayoum University Hospital from November 2011 till November 2012 and it included twenty cases with varicocele. The patients were divided into two groups: The first group (10 patients) was subjected to laparoscopic staple interruption for treatment of varicocele with cutting the gonadal vein or veins in between the clips, the second group (10 patients) was subjected to laparoscopic staple interruption for treatment of varicocele without cutting inbetween the clips.

Results: All the procedures in the two groups were completed satisfactorily, with no intraoperative complications. No significant difference was found in the operative time between the two groups (25.5 \pm 3.12 minutes and $26.2 \pm 4.23$ minutes for group I and II respectively) ( $p=0.889)$. Most patients in the two groups had moderate pain, with no significant difference between the two groups $(p=0.801)$. The hospital stay was not significantly different among the patients of the two study groups $(1.7 \pm 0.82$ days in group I and $1.5 \pm 0.68$ days in group II) $(p=0.870)$. There were no post operative complications, only one patient in the $2^{\text {nd }}$ group experienced recurrence symptoms of varicocele.

Conclusion: In conclusion, laparoscopic staple interruption for treatment of varicocele without cutting inbetween the clips is more superior to traditional laparoscopic staple interruption with cutting the gonadal vein or veins inbetween the clips for treatment of varicocele regarding the lower risk to cut the vas deference or spermatic artery. The spermatic count was the same as well as the spermatic motility and abnormal forms.
\end{abstract}

Key words: Varicocele, laparoscopic varicocelectomy, semen analysis, Palomo's operation.

\section{Introduction:}

Varicoceles have been associated with progressive deterioration of testicular function and testicular hypotrophy. ${ }^{1,2}$ Varicocele repair can halt or even reverse this progression. ${ }^{3}$ Over recent decades, varicocelectomy has developed with numerous approaches: microsurgical subinguinal (Goldstein), inguinal (Ivanissevich), and abdominal (Palomo, non artery sparing). Advantages of laparoscopic varicocelectomy include: increased magnification, facilitating more accurate identification of vessels, such as spermatic collateral veins, (i.e. veins running along side the spermatic cord and together entering the internal ring, a possible cause of recurrence if left alone), lymphatics (the ligation of which can lead to hydrocele formation) and the internal spermatic artery. 4,5 Moreover, laparoscopic varicocelectomy is safe even after prior inguinal surgery. The characteristic supra-inguinal access allows 
for high ligation of fewer veins vs. the subinguinal approach.

\section{Aim of the study:}

To compare the outcome including operative time, semen analysis, and complications between laparoscopic staple interruption for treatment of varicocele with cutting the gonadal vein or veins inbetween the clips and only application of the clips without cutting inbetween the clips

\section{Patients and methods:}

The present study involved 20 patients with symptomatic varicocele. These patients presented to Fayoum University Hospital outpatient clinic. They were subjected to clinical examination, pre-operative routine investigations, and pre-operative scrotal duplex. Clinical assessment included age, marital status, and history of having children, special habits of medical importance, complaint, urologic symptoms and local examination findings.

\section{Preoperative assessment included:}

1- Routine investigations including semen analysis.

2- Duplex study to determine the presence of reflux and the size of the spermatic veins.

These patients were randomly allocated into two groups depending on the procedure to be done:

Group A: 10 patients included post pubertal adolescents to be subjected to laparoscopic staple interruption for treatment of varicocele with cutting the gonadal vein or veins inbetween the clips. Four of them had bilateral varicoceles.

Group B: 10 patients included postpubertal adolescents to be subjected to laparoscopic staple interruption for treatment of varicocele without cutting inbetween the clips. Three of them had bilateral varicoceles.

\section{1- Group A (laparoscopic staple} interruption for treatment of varicocele with cutting the gonadal vein or veins inbetween the clips)

All patients were subjected to general anesthesia with endo-tracheal intubation. They were placed in the Trendlenburg position. Trans-peritoneal approach was carried out which consisted of induction of pneumo-peritoneum by insufflation of $\mathrm{CO}_{2}$ through an open technique through a supraumbilical mini-incision. As the pressure intra-abdominally reached $14 \mathrm{mmHg}$, a safety $10-\mathrm{mm}$ trocar sheath unit was introduced through the same incision. Pressure was then established at $12-14 \mathrm{mmHg}$. Through that port, a 0-degree scope was inserted and the abdominal cavity inspected. Two working ports were further introduced at a level just caudal to the umbilicus and lateral to the rectus muscle of both right and left lower quadrants. One of them was of 5-mm caliber and the other was of $10-\mathrm{mm}$ caliber. This array of trocars was used in either left or bilateral cases.

T-shaped peritoneal incision was made to provide ample exposure for access to the spermatic vascular bundle just cephalad to the internal inguinal ring. Freeing the entire spermatic vascular bundle from the surroundings was done. The spermatic artery was identified and isolated in an attempt for its preservation. The internal spermatic vein was individually clipped and divided using the 10-mm hemoclip applier.

\section{2- Group B (laparoscopic staple} interruption for treatment of varicocele without cutting inbetween the clips)

The same previous steps but the internal spermatic vein was individually clipped but not divided using the 10 -mm hemoclip applier.

\section{Post-operative Work-up:}

All patients of both groups were given parentral antibiotics (cefotaxime 1gm) i.v. 12 hours after the operation, and allowed oral liquid diet 12 hours after the operation. All patients were discharged 24 hours to return after one week to remove the stitches.

Clinical assessment of the patients as regards testicular pain, size of the testis and size of varicocele was done after 1 month.

Color coded duplex was done to all patients to assess the presence or absence of reflux and size of spermatic veins after 1 month. 


\section{Statistical analysis:}

Differences between means and the effects of treatments were detrmined by one-way ANOVA using Tukey's test, $\mathrm{P}<0.05$ was considered statistically significant.

\section{Results:}

The study included twenty cases with varicocele. They ranged in age from 19 to 42 years (mean $=25.5$ years). Table(1\&2).

The study included twenty cases with
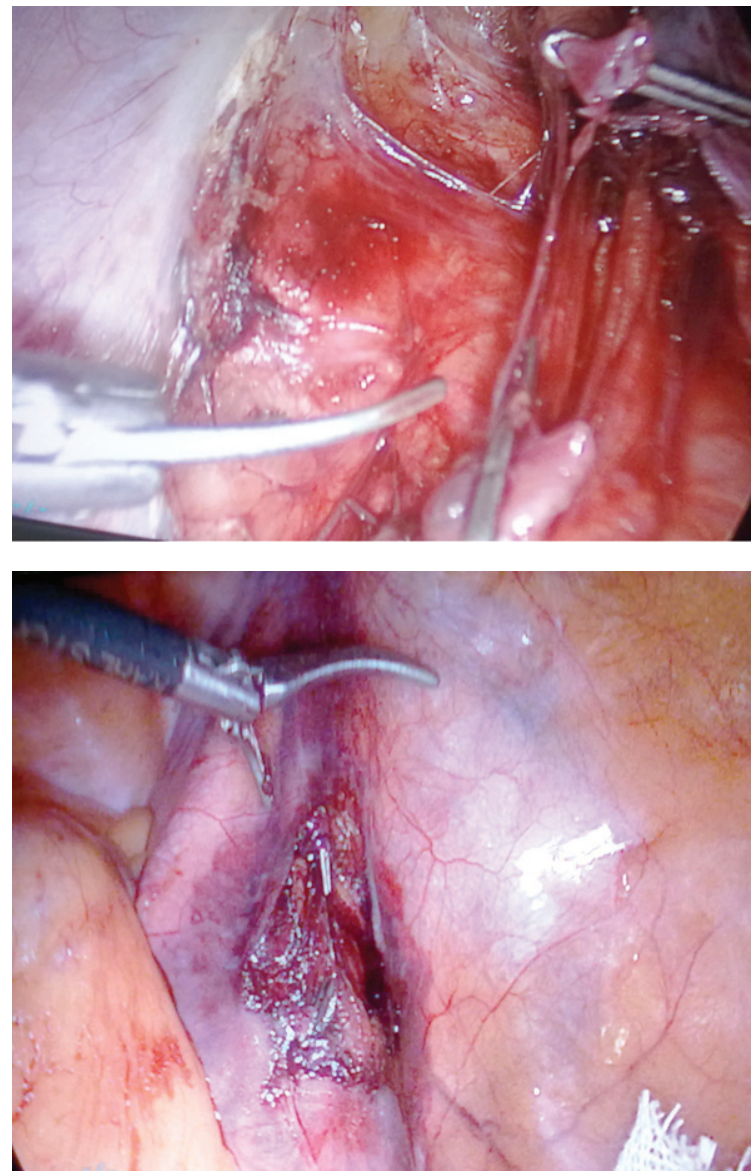

varicocele. They ranged in age from 19 to 42 years (mean $=25.5$ years). Table(1\&2).

The patients were divided into two groups according to the operative procedure done. The first group (10 patients) was subjected to laparoscopic staple interruption for treatment of varicocele with cutting the gonadal vein or veins inbetween the clips Figure(1). The second group (10 patients) was subjected to laparoscopic staple interruption for treatment of varicocele without cutting inbetween the clips Figure(2).
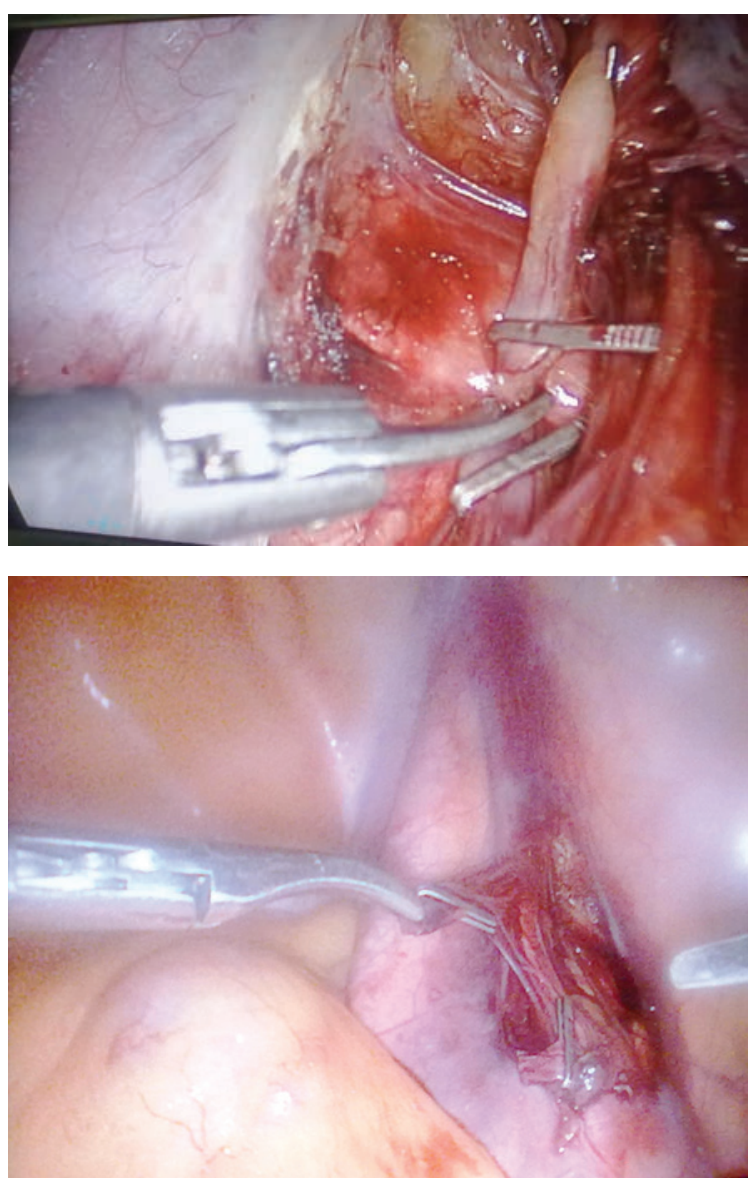

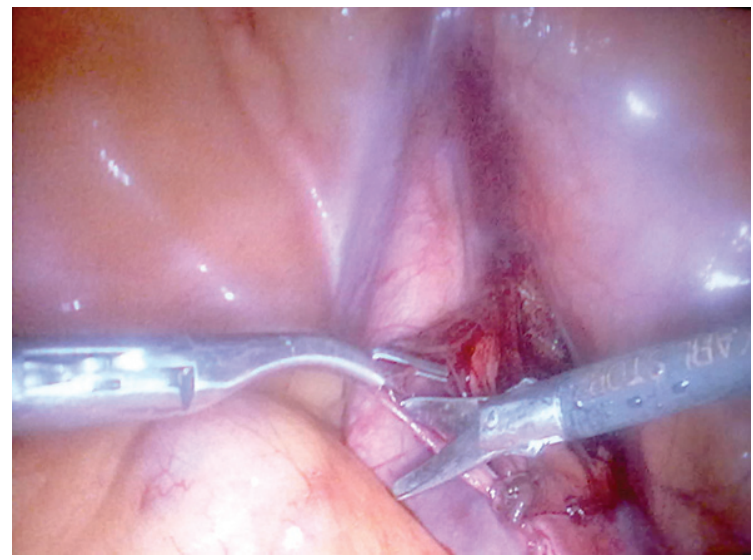

Figure (1 a,b,c,d\&e): Laparoscopic staple interruption for treatment of varicocele with cutting the gonadal vein or veins inbetween the clips. 

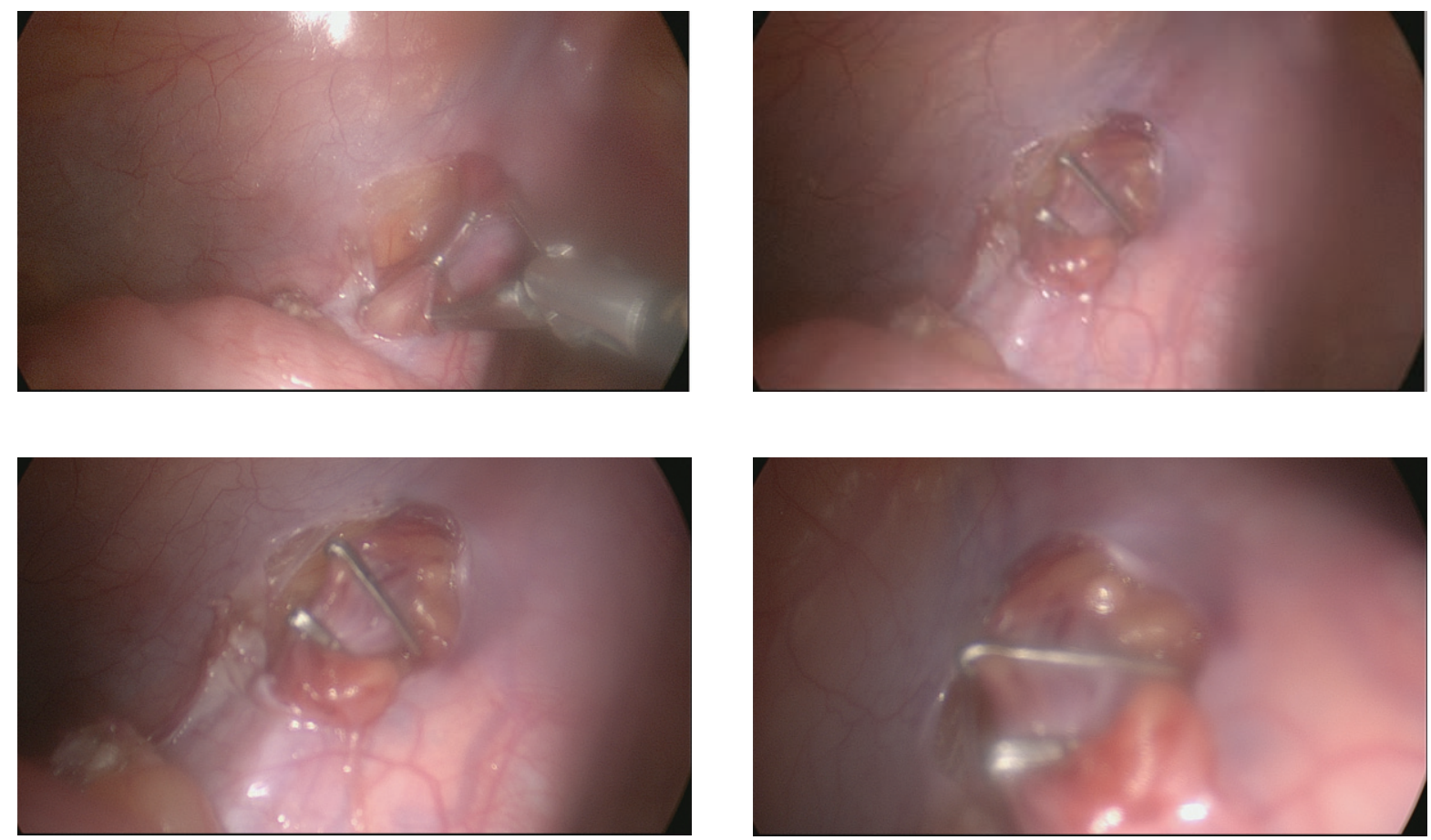

Figure (2 a,b,c,d): Laparoscopic staple interruption for treatment of varicocele without cutting inbetween the clips.

Table (1): Clinical data in group I with $\mathrm{u} / \mathrm{s}$ side.

\begin{tabular}{|c|c|c|c|c|c|}
\hline $\begin{array}{c}\text { Case } \\
\text { No. }\end{array}$ & $\begin{array}{c}\text { Age } \\
\text { (year) }\end{array}$ & $\begin{array}{c}\text { Presentation } \\
\text { (the most } \\
\text { distressing) }\end{array}$ & $\begin{array}{c}\text { Duration of } \\
\text { disease } \\
\text { (months) }\end{array}$ & $\begin{array}{c}\text { Side } \\
\text { (clinical) }\end{array}$ & $\begin{array}{c}\text { Side } \\
\text { (u/s) }\end{array}$ \\
\hline $\mathbf{1}$ & 30 & Swelling & 15 & Left & Bilateral \\
\hline $\mathbf{2}$ & 24 & Pain & 12 & Left & Left \\
\hline $\mathbf{3}$ & 19 & Infertility & 10 & Left & Bilateral \\
\hline $\mathbf{4}$ & 22 & Pain & 12 & Left & Left \\
\hline $\mathbf{5}$ & 27 & Swelling & 14 & Left & Bilateral \\
\hline $\mathbf{6}$ & 21 & Swelling & 20 & Left & Bilateral \\
\hline $\mathbf{7}$ & 23 & Infertility & 6 & Left & Bilateral \\
\hline $\mathbf{8}$ & 33 & Infertility & 30 & Bilateral & Bilateral \\
\hline $\mathbf{9}$ & 20 & Pain & 15 & Bilateral & Bilateral \\
\hline $\mathbf{1 0}$ & 28 & Pain & 22 & Left & Bilateral \\
\hline Mean & $24.7 \pm 8.3$ & - & $15.6 \pm 14.4$ & & \\
\hline & years & & Months & & \\
\hline
\end{tabular}


Table (2): Clinical data in group II with $\mathrm{u} / \mathrm{s}$ side.

\begin{tabular}{|c|c|c|c|c|c|}
\hline $\begin{array}{c}\text { Case } \\
\text { No. }\end{array}$ & $\begin{array}{c}\text { Age } \\
\text { (year) }\end{array}$ & $\begin{array}{c}\text { Presentation } \\
\text { (the most } \\
\text { distressing) }\end{array}$ & $\begin{array}{c}\text { Duration of } \\
\text { disease } \\
\text { (months) }\end{array}$ & $\begin{array}{c}\text { Side } \\
\text { (clinical) }\end{array}$ & $\begin{array}{c}\text { Side } \\
\text { (u/s) }\end{array}$ \\
\hline $\mathbf{1 1}$ & 26 & Pain & 14 & Left & Left \\
\hline $\mathbf{1 2}$ & 21 & Swelling & 30 & Left & Bilateral \\
\hline $\mathbf{1 3}$ & 30 & Pain & 8 & Left & Left \\
\hline $\mathbf{1 4}$ & 22 & Swelling & 20 & Left & Bilateral \\
\hline $\mathbf{1 5}$ & 26 & Infertility & 16 & Left & Left \\
\hline $\mathbf{1 6}$ & 24 & Swelling & 20 & Left & Left \\
\hline $\mathbf{1 7}$ & 28 & Swelling & 8 & Left & Bilateral \\
\hline $\mathbf{1 8}$ & 24 & Pain & 6 & Left & Left \\
\hline $\mathbf{1 9}$ & 42 & Infertility & 30 & Bilateral & Bilateral \\
\hline $\mathbf{2 0}$ & 20 & Swelling & 12 & Bilateral & Bilateral \\
\hline Mean & $26.3 \pm 15.7$ & & $16.4 \pm 13.6$ & & \\
\hline
\end{tabular}

Table (3): Comparison between the two groups regarding clinical features.

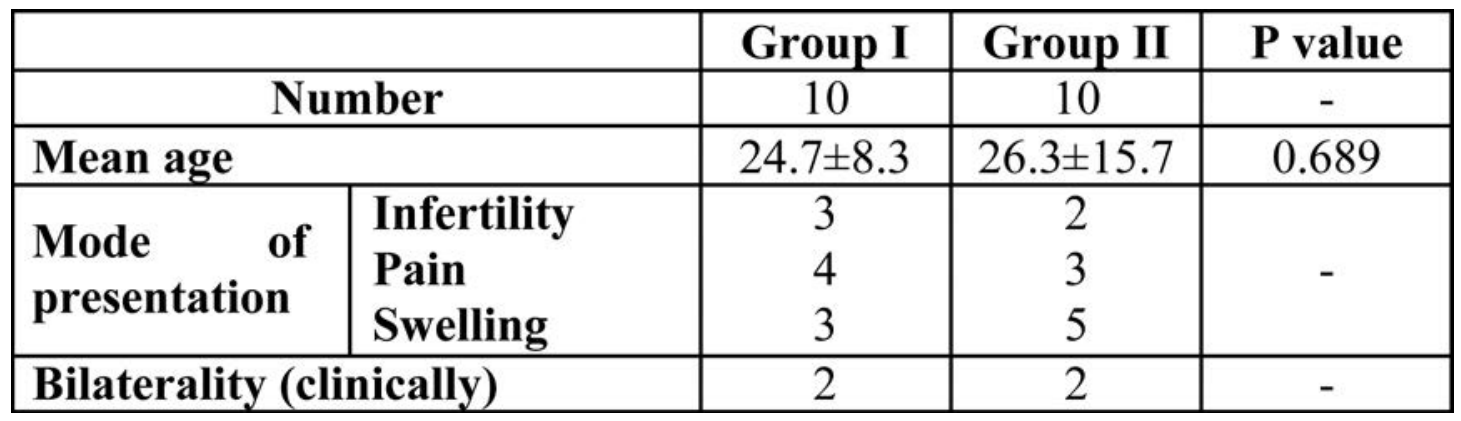


Table (4): Results of pre and postoperative $u / s$ examination.

\begin{tabular}{|c|c|c|c|c|c|c|c|c|}
\hline \multirow[t]{3}{*}{ No. } & \multicolumn{4}{|c|}{ Preoperative } & \multicolumn{4}{|c|}{ Postoperative } \\
\hline & \multicolumn{2}{|c|}{ Left side } & \multicolumn{2}{|c|}{ Right side } & \multicolumn{2}{|c|}{ Left side } & \multicolumn{2}{|c|}{ Right side } \\
\hline & Grade & $\begin{array}{l}\text { Testis } \\
\text { (cm) }\end{array}$ & Grade & $\begin{array}{l}\text { Testis } \\
\text { (cm) }\end{array}$ & Grade & $\begin{array}{l}\text { Testis } \\
\text { (cm) }\end{array}$ & Grade & $\begin{array}{l}\text { Testis } \\
\text { (cm) }\end{array}$ \\
\hline 1 & III & $4.5 \times 3 \times 2$ & II & $4 \mathrm{X} 3 \mathrm{X} 2$ & & $4 \mathrm{X} 3 \mathrm{X} 2$ & I & $4 \times 2.5 \times 2$ \\
\hline 2 & II & $4 X 3 X 2$ & $\mathrm{I}$ & $4 \times 2 \times 2.5$ & & $4 \mathrm{X} 3 \mathrm{X} 2$ & & $4 \times 2 \times 2.5$ \\
\hline 3 & II & $\begin{array}{c}3.7 \times 2.5 \\
\times 2\end{array}$ & & $\begin{array}{c}3.8 \mathrm{X} 2.5 \\
\mathrm{X} 2\end{array}$ & & $4 \times 2.5 \times 2$ & & $4 X 3 X 2$ \\
\hline 4 & II & $4.2 \times 3 \times 2$ & II & $4 \times 2.3 \times 2$ & & $4.1 \times 3 \times 2$ & I & $4 \times 2.2 \times 2$ \\
\hline 5 & III & $\begin{array}{c}4.2 X 2.8 \\
\times 2\end{array}$ & & $4 \times 2.7 \times 2$ & & $\begin{array}{c}4.2 \times 2.6 \\
X 2\end{array}$ & & $4 X 2.7 \times 2$ \\
\hline 6 & III & $\begin{array}{c}4.2 \times 2.6 \\
\text { X2 }\end{array}$ & I & $4 \times 2.6 \times 2$ & I & $4 X 2.5 \times 2$ & & $4.1 \times 2.5 \times 2$ \\
\hline 7 & II & $3.6 \times 2 \times 2$ & II & $\begin{array}{c}3.5 \times 2.6 \\
\times 2\end{array}$ & & $3 \times 2 \times 2$ & I & $3.5 \times 2.5 \times 2$ \\
\hline 8 & I & $4 \times 2 X 2$ & I & $4 X 2 X 2$ & & $4 \times 2 \times 2$ & $\mathrm{I}$ & $4 X 2 X 2$ \\
\hline 9 & $\overline{\text { II }}$ & $\begin{array}{c}4.3 \times 2.5 \\
\times 2\end{array}$ & $\mathrm{I}$ & $4.2 \times 2 \times 2$ & & $\begin{array}{c}4.2 \times 2.3 \\
\mathrm{X} 2\end{array}$ & & $4.1 \times 2 \times 2$ \\
\hline 10 & III & $3.8 \times 2 \times 2$ & I & $3.8 \times 2 \times 2$ & I & $3.5 \times 2 \times 2$ & I & $3.5 \times 2 \times 2$ \\
\hline 11 & II & $3 \times 2 \times 1.5$ & II & $3 \times 2 X 2$ & & $3 \times 2 \times 1.5$ & I & $3 \times 2 X 2$ \\
\hline 12 & II & $3 \times 2 \times 1.5$ & & $3 \times 2 \times 1.5$ & & $3 \times 2 X 1.5$ & & $3 \times 2 \times 1.5$ \\
\hline 13 & III & \begin{tabular}{|c|}
$4.2 \mathrm{X} 2.5$ \\
$\mathrm{X} 2$
\end{tabular} & II & $4 \times 2.5 \times 2$ & & $4 \times 2.5 \times 2$ & $\mathrm{I}$ & $4 \times 2.5 \times 2$ \\
\hline 14 & II & $4 \times 2.3 \times 2$ & I & $4 \times 2.1 \times 2$ & & $4 \times 2.1 X 2$ & & $4 \times 2.1 X 2$ \\
\hline 15 & $\mathrm{I}$ & $4.1 \times 2 \times 2$ & & $4.1 \times 2 \times 2$ & & $4 \times 2 \times 2$ & & $4.1 \times 2 \times 2$ \\
\hline 16 & III & $4 \times 2.7 \times 2$ & $\mathrm{I}$ & $4 \times 2.3 \times 2$ & & $4 \times 2.5 \times 2$ & & $4 \times 2.2 \times 2$ \\
\hline 17 & I & $4.2 \times 2 \times 2$ & & $4.2 \times 2 \times 2$ & & $4.1 X 2 X 2$ & & $4 \times 2 X 2$ \\
\hline 18 & II & \begin{tabular}{|c|}
$4.2 \times 2.5$ \\
$\mathrm{X} 2$
\end{tabular} & & $\begin{array}{c}4.1 X 2.5 \\
\times 2\end{array}$ & & \begin{tabular}{|c|}
$4.1 \mathrm{X} 2.3$ \\
$\mathrm{X} 2$
\end{tabular} & & $4 \times 2.4 \times 2$ \\
\hline 19 & III & $4.4 \times 2 \times 2$ & & $4.4 \times 2 \times 2$ & II & $4.2 \times 2 \times 2$ & I & $4.3 \times 2 \times 2$ \\
\hline 20 & I & $4 \times 2.2 \times 2$ & & $4 \times 2.1 \times 2$ & & $4 \times 2.1 X 2$ & & $4 \times 2.1 X 2$ \\
\hline
\end{tabular}

Table (5): A comparison between the two groups of patients preoperatively as regards their results of Duplex findings.

\begin{tabular}{|l|c|c|c|}
\hline & Group I & Group II & P value \\
\hline Bilaterality & 8 & 5 & - \\
\hline Mean Grade (left) & $2.3 \pm 1.3$ & $2 \pm 1$ & 0.832 \\
\hline Mean Grade (right) & $1.1 \pm 0.9$ & $0.6 \pm 1.4$ & 0.0000005 \\
\hline
\end{tabular}


Table (6): Results of pre and postoperative semen analysis.

\begin{tabular}{|c|c|c|c|c|c|c|c|c|c|c|}
\hline \multirow[b]{3}{*}{ No. } & \multicolumn{5}{|c|}{ Preoperative } & \multicolumn{5}{|c|}{ Postoperative } \\
\hline & \multirow[t]{2}{*}{$\begin{array}{c}\text { Count } \\
\text { X 10 } / \mathrm{ml}\end{array}$} & \multicolumn{3}{|c|}{$\begin{array}{c}\text { Motility\% } \\
\text { (hours) }\end{array}$} & \multirow{2}{*}{ 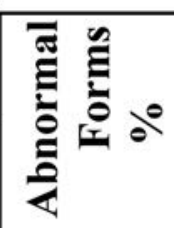 } & \multirow[t]{2}{*}{$\begin{array}{c}\text { Count } \\
\times 10^{6} / \mathrm{ml}\end{array}$} & \multicolumn{3}{|c|}{$\begin{array}{c}\text { Motility \% } \\
\text { (hours) }\end{array}$} & \multirow{2}{*}{ 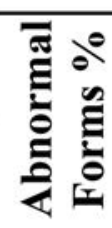 } \\
\hline & & $1^{\mathrm{st}}$ & $2^{\text {nd }}$ & $3^{\mathrm{rd}}$ & & & $1^{\mathrm{st}}$ & $2^{\mathrm{nd}}$ & $3^{\text {rd }}$ & \\
\hline 1 & 51 & 40 & 34 & 20 & 44 & 50 & 45 & 37 & 16 & 41 \\
\hline 2 & 29 & 22 & 16 & 10 & 38 & 48 & 30 & 19 & 14 & 35 \\
\hline 3 & 20 & 59 & 42 & 18 & 51 & 42 & 50 & 34 & 20 & 33 \\
\hline 4 & 25 & 33 & 23 & 14 & 49 & 40 & 39 & 30 & 20 & 47 \\
\hline 5 & 33 & 50 & 41 & 29 & 50 & 62 & 51 & 57 & 30 & 28 \\
\hline 6 & 21 & 20 & 11 & 6 & 44 & 35 & 26 & 21 & 11 & 36 \\
\hline 7 & 6 & 21 & 9 & \begin{tabular}{|l|}
17 \\
\end{tabular} & 75 & 9 & 31 & 20 & 14 & 65 \\
\hline 8 & 43 & 51 & 44 & \begin{tabular}{|l|}
29 \\
\end{tabular} & 14 & 51 & 66 & 43 & 28 & 43 \\
\hline 9 & 50 & 51 & 30 & 15 & 20 & 46 & 44 & 28 & 12 & 29 \\
\hline 10 & 15 & 50 & 39 & 35 & 40 & 12 & \begin{tabular}{|l|}
54 \\
\end{tabular} & 45 & 36 & 31 \\
\hline 11 & 13 & 32 & 22 & 9 & 60 & 13 & 30 & 21 & 22 & 59 \\
\hline 12 & 6 & 39 & 32 & 20 & 55 & 16 & 44 & 36 & 30 & 66 \\
\hline 13 & 11 & 33 & 20 & 26 & 17 & 19 & 39 & 20 & 37 & 25 \\
\hline 14 & 22 & 55 & 38 & 18 & 45 & 30 & 66 & 44 & 14 & 43 \\
\hline 15 & 31 & 55 & 38 & 40 & 63 & 30 & \begin{tabular}{|l|}
50 \\
\end{tabular} & 36 & 20 & 49 \\
\hline 16 & 60 & 43 & 33 & 25 & 25 & 60 & 66 & 41 & 26 & 20 \\
\hline 17 & 41 & 66 & 30 & 40 & 25 & 60 & \begin{tabular}{|l|}
70 \\
\end{tabular} & 54 & 43 & 20 \\
\hline 18 & 16 & 30 & 9 & 6 & 66 & 26 & 33 & 14 & 8 & 63 \\
\hline 19 & 11 & 54 & 44 & 30 & 50 & 31 & \begin{tabular}{|l|}
55 \\
\end{tabular} & 40 & 22 & 61 \\
\hline 20 & 17 & 62 & 39 & 19 & 30 & 41 & 65 & 39 & 38 & 24 \\
\hline
\end{tabular}

Table (7): A comparison between the two groups of patients preoperatively as regards their results of semen analysis.

\begin{tabular}{|l|c|c|c|}
\hline & Group I & Group II & P value \\
\hline Mean spermatic count x10 & 29.3 & 22.8 & 0.136 \\
\hline $\begin{array}{l}\text { Mean motility } \\
\mathbf{( 1}^{\text {st }} \text { hour) \% }\end{array}$ & 39.7 & 46.9 & 0.263 \\
\hline $\begin{array}{l}\text { Mean motility } \\
\left(\mathbf{2}^{\text {nd }} \text { hour) \% }\right.\end{array}$ & 28.9 & 30.5 & 0.708 \\
\hline $\begin{array}{l}\text { Mean Motility } \\
\mathbf{( 3}^{\text {rd }} \text { hour) \% }\end{array}$ & 19.3 & 23.3 & 0.359 \\
\hline Abnormal forms \% & 42.5 & 43.6 & 0.879 \\
\hline
\end{tabular}


Table (8): Comparison between group I and II pre and postoperatively regarding semen analysis findings.

\begin{tabular}{|c|c|c|c|c|c|}
\hline & Group I & Group II & P value \\
\hline \multirow{3}{*}{$\begin{array}{l}\text { Mean } \\
\text { spermatic } \\
\text { count } \times 10^{6}\end{array}$} & \multicolumn{2}{|c|}{ preoperative } & 29.3 & 22.8 & 0.136 \\
\hline & \multicolumn{2}{|c|}{ postoperative } & 39.5 & 32.6 & 0.220 \\
\hline & \multicolumn{2}{|c|}{ P value } & 0.063 & 0.0338 & - \\
\hline \multirow{9}{*}{$\begin{array}{c}\text { Mean } \\
\text { motility } \\
\text { percentage } \%\end{array}$} & \multirow{3}{*}{$\begin{array}{l}1^{\text {st }} \\
\text { hour }\end{array}$} & Preop. & 39.7 & 46.9 & 0.263 \\
\hline & & Postop. & 43.6 & 51.8 & 0.236 \\
\hline & & P value & 0.521 & 0.462 & - \\
\hline & \multirow{3}{*}{$\begin{array}{l}2^{\text {nd }} \\
\text { hour }\end{array}$} & Preop. & 28.9 & 30.5 & 0.708 \\
\hline & & Postop. & 33.4 & 34.5 & 0.862 \\
\hline & & $P$ value & 0.345 & 0.466 & - \\
\hline & \multirow{3}{*}{$\begin{array}{l}3^{\text {rd }} \\
\text { hour }\end{array}$} & Preop. & 19.3 & 23.3 & 0.358 \\
\hline & & Postop. & 20.1 & 26 & 0.179 \\
\hline & & P value & 0.823 & 0.531 & - \\
\hline \multirow{3}{*}{$\begin{array}{l}\text { Abnormal } \\
\text { forms \% }\end{array}$} & \multicolumn{2}{|c|}{ Preop. } & 42.5 & 43.6 & 0.887 \\
\hline & \multicolumn{2}{|c|}{ Postop. } & 39 & 43 & 0.521 \\
\hline & \multicolumn{2}{|c|}{ P value } & 0.631 & 0.928 & - \\
\hline
\end{tabular}

Table (9): Comparison between the two groups regarding operative time, postoperative pain and hospital stay

\begin{tabular}{|l|c|c|c|}
\hline & Group I & Group II & P value \\
\hline $\begin{array}{l}\text { Mean operative time } \\
\text { (minute) }\end{array}$ & $25.5 \pm 3.12$ & $26.2 \pm 4.23$ & 0.889 \\
\hline $\begin{array}{l}\text { Mean postoperative } \\
\text { pain (scale) }\end{array}$ & $5.7 \pm 2.22$ & $6.3 \pm 3.05$ & 0.801 \\
\hline $\begin{array}{l}\text { Mean hospital stay } \\
\text { (days) }\end{array}$ & $1.7 \pm 0.82$ & $1.5 \pm 0.68$ & 0.870 \\
\hline
\end{tabular}

All the procedures in the two groups were completed satisfactorily, with no intraoperative complications. No significant difference was found in the operative time between the two groups $(25.5 \pm 3.12$ minutes and $26.2 \pm 4.23$ minutes for group I and II respectively) ( $\mathrm{p}=0.889)$ Table(9).

Most patients in the two groups had moderate pain. According to the visual scale, the mean of group I was $5.7 \pm 2.22$ and of group II was $6.3 \pm 3.05$ with no significant difference between the two groups ( $\mathrm{p}=0.801$ ) Table(9).

The patients in the two groups were not different regarding the frequency and dosage of postoperative analgesics. The hospital stay was not significantly different among the patients of the two study groups $(1.7 \pm 0.82$ days in group I and $1.5 \pm 0.68$ days in group II) $(\mathrm{p}=0.870)$ Table(9).

At follow-up, none of the patients in the two groups had developed a postoperative 
hydrocele. Only one patient in the 2nd group experienced recurrent symptoms of varicocele.

\section{Discussion:}

A varicocele is an abnormal dilation of the pampiniform plexus that constitutes the primary drainage of the testis. It is found approximately in $15 \%$ of male adolescents. The majority of which is due to retrograde flow of blood in the internal spermatic vein. ${ }^{6}$

Several treatment options are available and include spermatic vein sclerotherapy or embolisation and open surgical ligation of the varix through a retroperitoneal, inguinal or a subinguinal approach. Laparoscopic varicocelectomy has been proposed as an alternative surgical procedure for the repair of varicocele with reported benefits of better convalescence, minimal invasiveness and less analgesic requirement post-operatively. It was reported as one of the most commonly performed laparoscopic procedures in surgery. ${ }^{7}$

The major advantage of the laparoscopic approach is that it provides a direct and magnified view of the structures allowing precise identification and dissection. It likewise allows a bilateral laparoscopic ligation to be done through the same incisions, instead of the two incisions required in an open surgical approach. However the main disadvantages of laparoscopy are the higher cost and the need for multiple port placements, which make it quite inappropriate in treating a unilateral varicocele. ${ }^{8}$

Varicoceles are most frequently diagnosed when a patient is $15-25$ years of age, and rarely develop after the age of $40 .{ }^{9}$

Our study included twenty cases with varicocele. They ranged in age from 19 to 42 years (mean $=25.5$ years). The patients were divided into two groups according to the operative procedure done. The first group (10 patients) was subjected to laparoscopic staple interruption for treatment of varicocele with cutting the gonadal vein or veins inbetween the clips. The second group (10 patients) was subjected to laparoscopic staple interruption for treatment of varicocele without cutting inbetween the clips. The patients were randomly distributed between the two groups.

Comparing the mean age of both groups, it was found that there was no significant difference between them (24.7 years and 26.3 years for group I and II respectively) $(p=0.689)$, denoting good matching of patients.

The mean duration of the disease in group I was 15.6 months and 16.4 months in group II with no statistically significant difference $(\mathrm{p}=0.847)$. In an experimental study ${ }^{10}$ it was found that there was significant increase in apoptosis at the end of the first month in the varicocele cases and that this apoptosis continued with time. Because the histopathologic injury, which is parallel to apoptosis, increased, they believe that treatment in the early phase of varicocele is important for prevention of probable injury.

Varicoceles are implicated in $70 \%$ to $80 \%$ of men with secondary infertility. ${ }^{11}$ It was found in our study that infertility represented the most common presentation in our patients (40\%) (30\% in group I and 50\% in group II), followed by pain (35\%) and swelling which represented (25\%).

It was noticed that the mean age of the infertility cases (28.38 years) was larger than that of the pain cases (25.71 years) and that of the swelling cases (24.4 years).

Physical examination in a warm room is the mainstay of diagnosis of varicocele, but this is affected by a low sensibility and specificity, especially in cases of low grade varicocele. The sensitivity and specificity of varicocele detection approaches $100 \%$ with color Doppler ultrasound. ${ }^{12}$ Color Doppler ultrasound will certainly become the gold standard in the investigation of varicocele. 13,14

In this work, color Doppler study revealed additional nine cases with bilateral disease that were not detected clinically.

Primary varicocele, by far is more common on the left side in approximately $90 \%$ of cases, it is bilateral in 8 to $9 \%$ and is right sided in 1 to $2 \% .{ }^{15}$ Abnormality apparently has a high bilateral prevalence (80.7\%). This may suggest that we should consider varicocele as a bilateral disease. This result coincided with 
our study.

In a study it was found that varicocele repair in adults with a clinical left varicocele increased left testicular volume and improved semen profiles. ${ }^{16}$ In contrary, in our study, no changes have been detected regarding testicular volume following varicocelectomy.

Varicocele is a very common pathology in infertile men, but it is unclear whether only one common pathway or whether multiple mechanisms negatively affect spermatogenesis. Therefore, varicocele may be associated with a variety of spermatogenic conditions, ranging from completely normal seminal parameters to moderate oligo spermia or azoospermia. Different researchers have focused upon the effect of varicocele in the function and number of human sperm cells and sperm characteristics. ${ }^{17,18,19}$ Varicocele causes damage to sperm DNA and changes sperm motility. ${ }^{20}$

Comparing the preoperative semen parameters of patients in both groups, there were no statistically significant difference regarding the mean spermatic count (29.3 $\mathrm{x} 106 / \mathrm{ml}$ and $22.8 \mathrm{x} 106 / \mathrm{ml}$ in group I and II respectively) $(\mathrm{p}=0.136)$, the mean spermatic motility after one hour (39.7\% and $46.9 \%$ in group I and II respectively) ( $\mathrm{p}=0.263$ ), the mean spermatic motility after two hours $(28.9 \%$ and $30.5 \%$ in group I and II respectively) ( $p=0.708)$, the mean spermatic motility after three hours $(19.3 \%$ and $23.3 \%$ in group I and II respectively) ( $\mathrm{p}=0.359)$ and the mean of the abnormal forms $(42.5 \%$ and $43.6 \%$ in group I and II respectively) ( $\mathrm{p}=$ 0.879 ).

Comparing the postoperative semen parameters of patients in both groups, there was significant increase in the mean spermatic count in group I (from $29.3 \times 106 / \mathrm{ml}$ to 39.5 $\mathrm{x} 106 / \mathrm{ml})(\mathrm{p}=0.063)$ and (from $22.8 \times 106 /$ $\mathrm{ml}$ to $32.6 \times 106 / \mathrm{ml})(\mathrm{p}=0.033)$ in group II $\mathrm{p}<0.05$, thus the improvement in spermatic count shows significant difference between the two groups.

In a study it was found that the improvement in spermatic motility after one hour was from $28.42 \% \pm 23.22 \%$ to $39.92 \% \pm 22.06 \%$ in their patients post-varicocelectomy. ${ }^{21}$
In our study, it was observed that the spermatic motility improved in both groups postoperatively after $1^{\text {st }}, 2^{\text {nd }}$ and $3^{\text {rd }}$ hours; although, the improvement was statistically insignificant.

In our study, it was observed that there was no significant improvement regarding abnormal forms in group I $(\mathrm{p}=0.631)$, or in group II ( $\mathrm{p}=0.928)$.

In this work the procedures in the two groups were completed satisfactorily, with no intra-operative complications. No significant difference was found in the operative time between the first and second groups (25.5 minutes and 26.2 minutes for group I and II respectively) ( $\mathrm{p}=0.889$ ).

Most of patients in the two groups had moderate postoperative pain. According to the visual scale, the mean of group I was 5.7 and of group II was 6.3 with no significant difference between the two groups ( $\mathrm{p}=0.801$ ).

The patients in the two groups showed no difference regarding the frequency and dosage of postoperative analgesics.

The hospital stay was not significantly different among the patients of the two study groups (1.7 days in group I and 1.5 days in group II) ( $\mathrm{p}=0.870)$.

The most frequent complication of varicocelectomy was hydrocele formation, occurring in as many as $30 \%$ of the patients. The etiology is likely that of lymphatic obstruction, evidenced by the high average protein content of post varicocelectomy hydroceles compared to that of edematous fluid produced by venous obstruction. ${ }^{22}$ However, none of our patients developed a postoperative hydrocele.

In our study in all cases, identification of the testicular artery was done successfully. In a study aiming to determine if laparoscopic varicocelectomy with preservation of the testicular artery is a satisfactory alternative to standard open surgical techniques in adolescents it was found that the laparoscopic technique with preservation of the testicular artery is an acceptable alternative to open surgical treatment of varicoceles. Further, it eliminates the risk of testicular atrophy and it is the technique of choice when previous 
inguinal surgery has been performed. ${ }^{23}$

\section{Conclusion:}

Laparoscopic staple interruption for treatment of varicocele without cutting inbetween the clips is more superior to traditional laparoscopic staple interruption for treatment of varicocele with cutting the gonadal vein or veins inbetween the clips especially regarding the lower risk to cut the vas deference or spermatic artery, and spermatic count with the same results regarding spermatic motility and abnormal forms.

A limitation of the present study was the absence of a control group of observation or no treatment to add to the debate on the real value of varicocelectomy in treating male infertility.

\section{References:}

1- Canutes BK, Nakib N, Lavers A, et al: Male varicoceles, in male reproductive dysfunction: Pathophysiology and treatment. Kandeel FR, Swerdloff RS, Pryor JL (Editors); Jay \& Francis (Publishers); chapter 15, $1^{\text {st }}$ edn.; 2007; p. 183-196.

2- Casale P: Report on varicocele and infertility. Fertility Sterility Journal 2006; 86(4): 93-95.

3- Cayan S, Lee D, Black ID, et al: Response to varicocelectomy in oligospermic men with and without defined genetic infertility. Urology Journal 2001; 57(3): 530-555.

4- Beck, Goldstein: Varicocele anatomy: A macro and microscopic study. American Urological Association Annual Meeting, Toronto 1991; (5): 16.

5- Amelar RD: Early and late complications of inguinal varicocelectomy. Urology Journal 2003; 170 (2Pt l): 366-369.

6- Schneck FX, Bellinger MF: Abnormalities of the testes and scrotum and their surgical management. In: Campbell's urology. Walsh PC, RetikAB (Editors); Elsevier (Publisher); volume 3, $8^{\text {th }}$ edn.; 2002; p. 3695-3697.

7- Kass EJ, Stork BR, Steinert BW: Varicocele in adolescence induces left and right testicular volume loss. International British Journal of Urology 2001; 87: 499-501.

8- Sihoe D, Magsanoc N, Sreedhar B, et al: Laparoscopy in pediatric urology. Recent advances. Hong Kong Journal of Pediatrics 2004; 9: 65-73.

9- Rudloff U, Holmes RJ, Prem JT, et al: Mesoaortic compression of the left renal vein (nutcracker syndrome): Case reports and review of the literature. Annals of Vascular Surgery 2006; 20 (1): 120-129.

10-Gtirdal M, Kireti S, Him E et al: Correlation between duration of varicocele and apoptosis in testicular tissue in an experimental model. IC Surg Urology Journal 2008; 175 (2): 33.

11-Fretz PC, Sandlow JI: Current concepts in pathophysiology, diagnosis and treatment. Urologic Clinical Journal of North America 2002; 29: 921-937.

12-Penson DF, Paltiel AD, Krumholz HM, et al: The cost-effectiveness of treatment for varicocele related infertility. Urology Journal 2002; (168): 2490-2494.

13-Dogra V, Gottlieb R, Oka M, et al: Sonography of the scrotum. Radiology Journal 2003; 227:18-36.

14-Liguori G, Trombetta C, Garaffa G, et al: Color Doppler ultrasound investigation of varicocele. World Journal of Urology 2004; 22(5): 378-381.

15-Bakal CW, Silberzweig J, Cynamon J: Vascular and interventional radiology: Principles and practice. Bakal CW, Silberzweig J, Cynamon J (Editors); Thieme (Publisher); $1^{\text {st }}$ edn.; 2002; p. 318.

16-Sakamoto H, Saito K, Ogawa Y, et al: Effects of varicocele repair in adults on ultrasonographically determined testicular volume and on semen profile. Urology Journal 2008; 71(3): 485-489.

17-Zini A, Defreitas G, Freeman M, et al: Varicocele is associated with abnormal retention of cytoplasmic droplets by human spermatozoa. Fertility Sterility Journal 2000; (74): 461- 464.

18-Hauser R, Paz G, Botchan L, et al: Varicocele: Effect on sperm functions. Human Reproduction Update 2001; (7): 
482- 485.

19-Ziemba H, Bialy LP, Fracki S, et al: Proteasome localization and ultrastructure of spermatozoa from patients with varicocele-immunoelectron microscopic study. Folia Histochempetability Cytobiology Journal 2002; (40): 169-170.

20-Tang J, Yan SW, Zhang N, et al: Influence of varicocele on sperm chromatin structure and sperm motility. Zhonghua Nan Ke Xue Journal 2007; 13(8): 690-692.

21-Ishikawa T, Fujisawa M: Effect of age and grade on surgery for patients with varicocele. Urology Journal 2005; 65(4):
768-772.

22-Cayan S, Kadioglu TC, Tefekli A et al: Comparison of results and complications of high ligation surgery and microsurgical high inguinal varicocelectomy in the treatment of varicocele. Urology Journal 2000; 55(5): 750-754.

23-Cohen R: Laparoscopic varicocelectomy with preservation of the testicular artery in adolescents. Pediatr Journal 2001; 36(2): 394-396. 